\title{
Serial arterial spin labeling MRI in autonomic status epilepticus due to anti-LGI1 encephalitis
}

Figure $1 \quad$ Neuroimaging before treatment of autonomic status epilepticus due to anti-LGI1 encephalitis
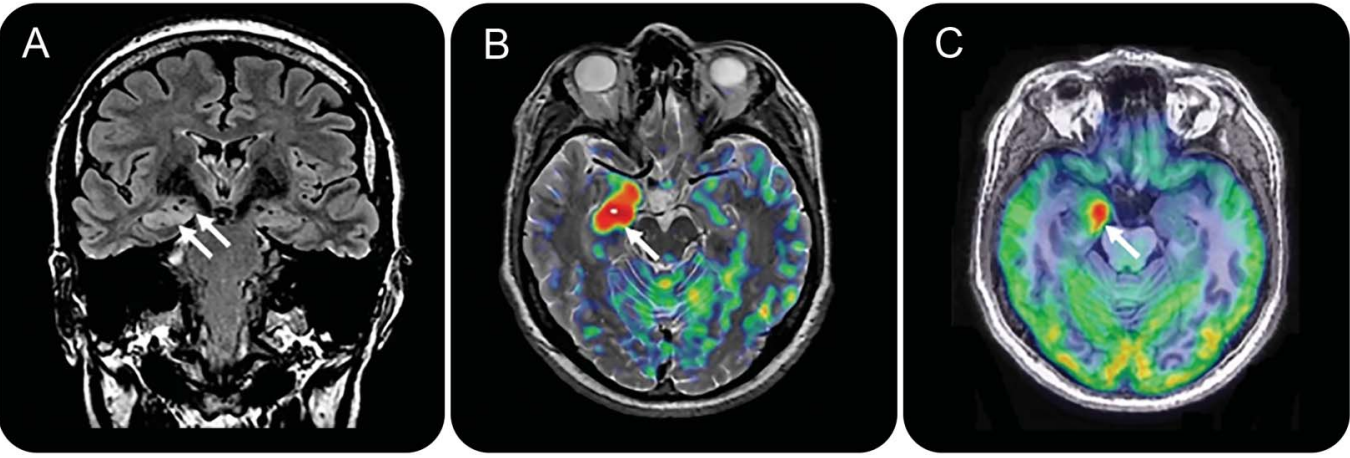

At the acute stage of the disease, coronal fluid-attenuated inversion recovery sequence (A) shows hyperintensity of the right hippocampus and amygdala (arrows), while arterial spin labeling (B) and ${ }^{18} \mathrm{~F}-\mathrm{FDG}-\mathrm{PET}$ (C) depict marked hyperperfusion/hypermetabolism circumscribed only to these 2 structures (arrows), being caused by highly repetitive seizures.

A 56-year-old man presented with a 1-month history of daily autonomic seizures (tachycardia, diaphoresis, and nausea). Diagnosis of limbic encephalitis was confirmed based on brain MRI findings and anti-LGI1 antibodies found in CSF. Autonomic status epilepticus was diagnosed on a video-EEG study, while arterial spin labeling (ASL) sequences and ${ }^{18}$ F-FDG-PET (figure 1) showed hyperperfusion/hypermetabolism over the hippocampus and amygdala. Follow-up neuroimaging (figure 2) proved improvement of the findings as the patient responded to treatment. ASL is an imaging technique highly sensitive to changes in regional cerebral blood flow that can help in the evaluation and follow-up of patients with epilepsy. ${ }^{1,2}$

Figure 2 Neuroimaging after treatment of autonomic status epilepticus due to anti-LGI1 encephalitis
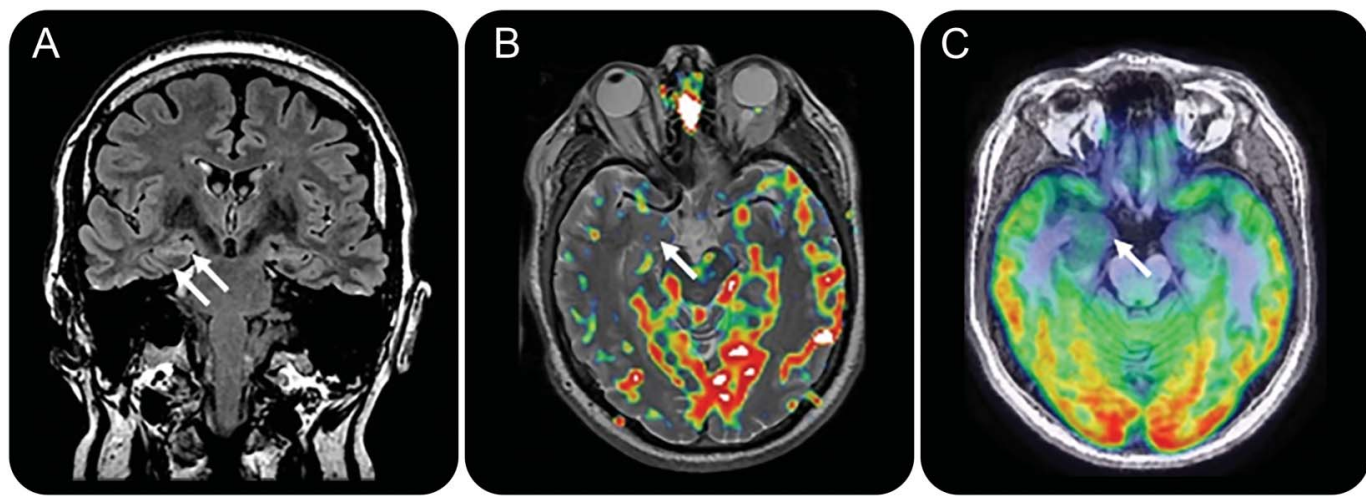

Epilepsy was controlled on inmunomodulatory therapy. One year after treatment, follow-up coronal fluid-attenuated inversion recovery sequence (A) shows complete resolution of the inflammation involving the temporal medial region (arrows), whereas ASL (B) and ${ }^{18}$ F-FDG-PET (C) show slightly decreased blood perfusion and metabolism of the hippocampus and amygdala (arrows). 
From the Hospital Occidente de Kennedy (C.E.-J.), Bogotá, Colombia; Hospital Ruber International (R.T., I.G.-M., J.Á.-L., A.G.-N.); Hospital Ramón y Cajal (R.T.); and Hospital Clínico San Carlos (I.G.-M.), Madrid, Spain.

Author contributions: Dr. Espinosa-Jovel and Dr. Toledano: study concept and design, acquisition of data, analysis and interpretation of data, critical revision of manuscript for intellectual content. Dr. García-Morales: critical revision of manuscript for intellectual content. Dr. Álvarez-Linera: interpretation of data and critical revision of manuscript for intellectual content. Dr. Gil-Nagel: study supervision and critical revision of manuscript for intellectual content.

Study funding: No targeted funding reported.

Disclosure: The authors report no disclosures relevant to the manuscript. Go to Neurology.org for full disclosures.

Correspondence to Dr. Espinosa-Jovel: camilo_jovel@hotmail.com

1. Sierra-Marcos A, Carreño M, Setoain X, et al. Accuracy of arterial spin labeling magnetic resonance imaging (MRI) perfusion in detecting the epileptogenic zone in patients with drug-resistant neocortical epilepsy: comparison with electrophysiological data, structural MRI, SISCOM and FDG-PET. Eur J Neurol 2016;23:160-167.

2. Boscolo Galazzo I, Storti SF, Del Felice A, et al. Patient-specific detection of cerebral blood flow alterations as assessed by arterial spin labeling in drug-resistant epileptic patients. PLoS One 2015;10:e0123975.

\section{Complimentary CME and Self-assessment Resources: An Exclusive AAN Membership Benefit!}

Looking for ways to earn important CME credits in 2016? Look no further, because AAN membership provides FREE* access to the AAN's suite of online learning programs: NeuroSAE ${ }^{\circledR}$, NeuroLearn ${ }^{\mathrm{SM}}$, and NeuroPI ${ }^{\mathrm{SM}}$. Access from virtually anywhere-home or office-to meet your CME needs, as well as take the necessary steps toward fulfilling your maintenance of certification (MOC) requirements, as mandated by the ABPN. Visit AAN.com/view/MOC today!

*Free access is limited to one course per program at a time.

\section{WriteClick ${ }^{\circledR}$ rapid online correspondence}

The editors encourage comments about recent articles through WriteClick:

Go to Neurology.org and click on the "WriteClick" tab at the top of the page. Responses will be posted within 72 hours of submission.

Before using WriteClick, remember the following:

- WriteClick is restricted to comments about studies published in Neurology within the last eight weeks

- Read previously posted comments; redundant comments will not be posted

- Your submission must be 200 words or less and have a maximum of five references; reference one must be the article on which you are commenting

- You can include a maximum of five authors (including yourself) 


\section{Neurology}

\section{Serial arterial spin labeling MRI in autonomic status epilepticus due to anti-LGI1 encephalitis}

Camilo Espinosa-Jovel, Rafael Toledano, Irene García-Morales, et al. Neurology 2016;87;443-444

DOI 10.1212/WNL.0000000000002903

\section{This information is current as of July 25, 2016}

\section{Updated Information \& Services}

References

Citations

Subspecialty Collections

Permissions \& Licensing

Reprints including high resolution figures, can be found at: http://n.neurology.org/content/87/4/443.full

This article cites 2 articles, 0 of which you can access for free at: http://n.neurology.org/content/87/4/443.full\#ref-list-1

This article has been cited by 2 HighWire-hosted articles: http://n.neurology.org/content/87/4/443.full\#\#otherarticles

This article, along with others on similar topics, appears in the following collection(s):

All Epilepsy/Seizures

http://n.neurology.org/cgi/collection/all_epilepsy_seizures

Autoimmune diseases

http://n.neurology.org/cgi/collection/autoimmune_diseases

PET in epilepsy

http://n.neurology.org/cgi/collection/pet_in_epilepsy

Status epilepticus

http://n.neurology.org/cgi/collection/status_epilepticus

Information about reproducing this article in parts (figures,tables) or in its entirety can be found online at:

http://www.neurology.org/about/about_the_journal\#permissions

Information about ordering reprints can be found online:

http://n.neurology.org/subscribers/advertise

Neurology ${ }^{\circledR}$ is the official journal of the American Academy of Neurology. Published continuously since 1951, it is now a weekly with 48 issues per year. Copyright () 2016 American Academy of Neurology. All rights reserved. Print ISSN: 0028-3878. Online ISSN: 1526-632X.

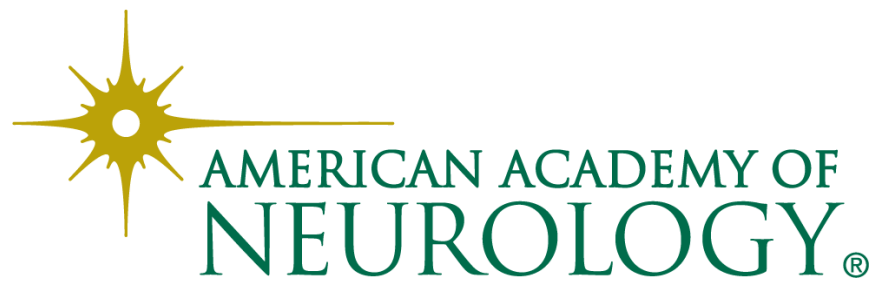

